\title{
Identification and Mapping of Tourism Potential in Agropolitan Area Pacitan Regency
}

\author{
Rizha Hardyansah ${ }^{1}$, Luchman Hakim ${ }^{2}$, Rita Parmawati ${ }^{3}$ \\ \{hardyansah.rizha@gmail.com¹ ${ }^{1}$ luchman@ub.ac.id ${ }^{2}$,rita_parmawati@ub.ac.id ${ }^{3}$ \} \\ Universitas Brawijaya, Indonesia ${ }^{1,2,3}$
}

\begin{abstract}
Tourism is a potential services sector, integrating it with Agropolitan concept to support rural area development is necessary. The aim of this study is to map tourism potentials based on 3A, namely Attraction, Amenity, and Accessibility. Conducted indepth interviews with informants used a qualitative descriptive method and used QGIS 2.18 to analyze, identify, and map the tourism potential destinations in Agropolitan Area Pacitan Regency. The attraction identified in Agropolitan Area are Waterfall (Sabun Waterfall and Watu Senthe River Waterfall), Plateau (Meru Mount, Gembes Mount, and Petuk Gua Mount), Cave (Gajah Barong Cave), and part of rural tourism (Ketek Ogleng Dance, a bamboo weaving center, traditional coffee processing, and the Rice Terrace). Amenity component shows that there is one lodging in Pakisbaru Village with an option to sleep in a local resident house and camping in the surrounding area of natural attractions. Accessibility component shows that transportation facilities to get to the Agropolitan Area are still limited. The synergy between all components can encourage the development of excellent and sustainable tourism so that it can improve the economy of the community around the Agropolitan Area Pacitan Regency.
\end{abstract}

Keywords: Agropolitan, Accessibility, Amenity, Attractions, Tourism.

\section{Introduction}

Agropolitan is a bottom-up type strategy of development planning based on agricultural activities, and the objectives is to accelerate regional and agribusiness development in the surrounding area that consists of one or more activity located in rural areas. In this area, there is a system and management of agriculture and the other resources indicated by the existence of functional linkages and a spatial hierarchy of the settlement and agribusiness systems [1]. The concept offered by Friedman and Douglas makes development concentrated in the village with a population of 50.000 to 150.000 people [2].

In Indonesia, Agropolitan strategy can be integrated with other sectors such as trade, industry, and services in order to support the development of the agriculture, rural area, and also support the development of the other sectors. Which will indirectly affect the welfare of the community. The potential developed sector is services, such as tourism. It is because tourism has become one of the global phenomena that are highly developed from year to year and contributing to the global economy [3]. In Indonesia, the tourism sector contributes to increase the Gross Domestic Product (GDP) because of the unique landscape and high biodiversity. It makes Indonesia is a destination that considered by foreign tourists, indicated by the increase of foreign tourist visits in several years [4]. 
There are still many tourism potentials that can be developed to improve the economy of a region, and this is included in the tourism planning process [5]. In the development of tourism there is a framework consists of three components, namely Attractiveness, Amenity, and Accessibility [6]. Attractions an attraction for tourists to come because of something unique and interesting in that place. Amenity is the existence of various facilities such as places to stay, restaurants, entertainment, local transportation, which allows tourists to travel there and other communication tools. Accessibility is a component related to the ease of tourist destinations to reach regardless of physical limitations and age.

The problem of tourism development and planning is integration of community land use for tourism destinations and community-managed land still rarely solved [7]. So, it needs a mapping of tourism potentials, so that a region or country can still compete with other regions to increasing the tourism sector growth [8]. One way that can be used is to use a Geographic Information System (GIS). GIS can be a spatial tourism potential analysis tool and can be used as a basis in development planning and tourism development [9], so the aim of this study is to identify and mapping tourism potentials that include of Attractiveness, Amenity, and Accessibility based on Geographic Information Systems (GIS).

\section{Research Methods}

\subsection{Study Area}

This research was conducted in the Agropolitan Area Pacitan Regency, with an area approximately $241,4 \mathrm{~km}^{2}$. It consists of Bandar and Nawangan District (Figure 1), also has averaged between 500-1,150 meters above sea level. There was one tourism destination managed by Regional Government, namely Jendral Soedirman Monument, located in Pakisbaru Village, Nawangan District, Pacitan Regency.

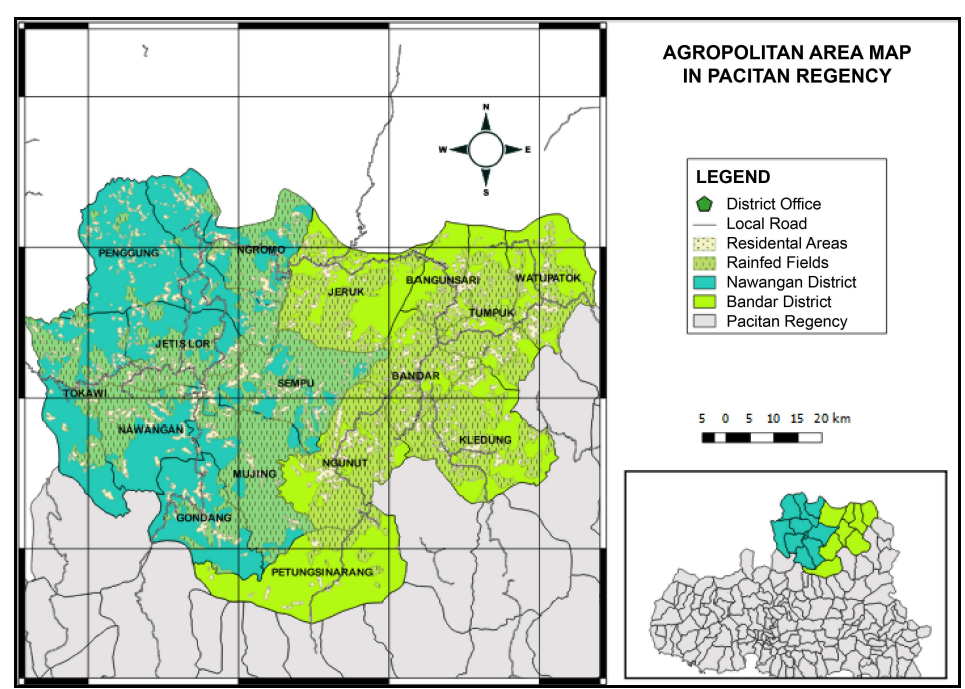

Fig 1. Map of Agropolitan Area Pacitan Regency. 


\subsection{Data Collection}

This research used descriptive qualitative methods, data collection used Secondary Data Review (SDR), and interviews with key informants. Key informants in this study were the Head of the Community Empowerment and Welfare Section of Bandar and Nawangan Districts, the Pacitan Regency Tourism Office, and community leaders in the Agropolitan Area Pacitan Regency.

\subsection{Data Analysis}

The interview data was used as a part of participatory asset mapping to establish tourism potential in Agropolitan Area. Participatory asset mapping is an information obtained from community to compile a map of the assets in the area. It considered as a holistic method of mapping. The base map used in this research was an RBI map obtained from the Indonesia Geospatial Portal, and then mapping was analyzed using QGIS 2.88.

\section{Results and Discussion}

Bandar and Nawangan district have a category 5 of slope level (mountains), with an elevation approximately 500-1000 meters above sea level. Climate and rainfall are influence by geographic conditions. The average of rainfall is $1921 \mathrm{~mm} / \mathrm{year}$ and the temperatures between $22-26^{\circ} \mathrm{C}$. Bandar District has eight villages, namely Petungsinarang, Ngunut, Bandar, Kledung, Watupatok, Bangunsari, and Jeruk. Nawangan District has nine villages, namely Gondang, Mujing, Sempu, Nawangan, Penggung, Tokawi, Pakisbaru, Ngromo, and Jetis Lor.

The map of potential tourism destination shows that there are at least 10 potential tourism destination. The Secondary Data Review on government and statistical documents shows a general description of the location, and then the interview with key persons show about the potential tourism destination. A map showing a potential tourism destination is shown in Figure 2.

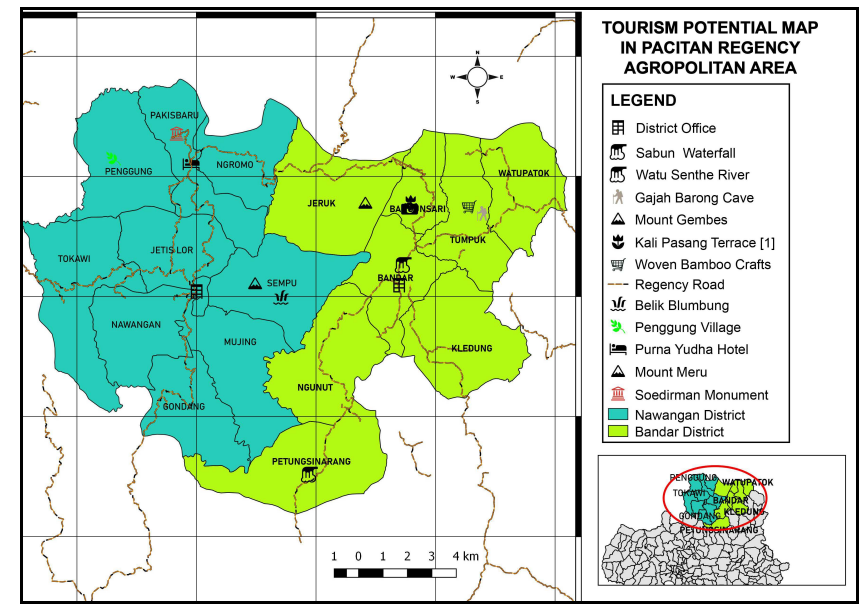

Fig 2. The map of potential tourism destination in Agropolitan Area 


\subsection{Attractions}

Based on Figure 2, there are several tourism destinations that have potential to be developed as an attraction to improve economic level and development of the community in Agropolitan Area. The potentials including Waterfall (Curug), Cave, Plateau (Mountain/Hill), Handicraft Center, Plantation, Culture, and Springs.

Sabun Waterfall and Watu Senthe River Waterfall are potential destinations because it has beautiful scenery and natural condition. Majority of the land used in surrounding area are rainforest and rain-fed rice fields. Management of this tourism has been carried out by the community with the withdrawal of entry tickets for tourists who will visit. Waterfalls can be used as ecotourism destinations, sustainable nature tourism, and religious tourism [10] [11]. Waterfall-based tourism can be developed in terms of outdoor activities such as hunting, fishing, camping, and trekking. However, these activities are plenty harmful for the quality of surrounding ecosystems. It can produce pollution, initiate forest destruction, and a decrease in the number of important species, so it needs more government and expert to establish the type of development that considers conservation and sustainable development aspects, but still the local community will be the one that manage the area as tourism manager [12].

Plateau is characteristic of Agropolitan Area Pacitan Regency, so based on identification results shows that there are many mountains or hills. Mountains or hills that have been identified and mapped are Mount Petung Gua, Mount Gembes, and Mount Meru. Based on the interview, Mount Petung Gua has a sunrise spot with moderate accessibility, Mount Gembes has a scenery viewpoint, and also for Mount Meru. At present, natural resources have begun to be observed to be used as tourism to meet world tourism demand; a mountain can be used as a tourist destination to support the development of tourism in a country [13]. However, majority of mountain-based nature tourism is mass tourism, so it needs a management plan and development of mountain-based natural tourism areas into sustainable nature tourism. It must be done to prevent environmental damage and ecosystem changes by tourists going to the mountains [14]. The cave that has been identified in Agropolitan Area is Gajah Barong Cave, precisely in Bandar District. It is a natural cave that recently discovered by the community, and still, in the process of excavation and opening, the village government expects assistance for the development of this location into a prominent tourist destination. Based on the interview, components that can be enjoyed by tourists are the beauty of the cave and the place to see the sunset over the cave or the cave exit. Cave tourism is one of the attractions that are being sought by the public to be able to enjoy the beauty of nature [15]. As a natural resource that has the potential to be developed, this type of tourism can improve the economy of local communities also help the government in educating the public and tourists about the importance of protecting the environment [16][15].

The other identified and mapping potential can be grouped into rural tourism. It is one of the tourism concepts by utilizing the potential in the village, both culture, habits, special products, and natural beauty. Rural tourism offers new experiences to tourists; this is driven by the desire of tourists to reminisce with the past, unite with nature, relax, and enjoy the state far from the crowd in the city. [17] [18]. The potential for rural tourism development in the Agropolitan Area consists of the Ketek Ogleng Dance, a bamboo weaving center, traditional coffee processing, and the Rice Terrace. Ketek Ogleng Dance is a traditional dance that was invented by Mr. Sutiman from Tokawi Village, Bandar District, this dance was based on monkey movements in the forest. It has been entered intellectual property owned by Pacitan Regency and is often displayed both inside and outside the area. Bamboo weaving centers can 
be encouraged to be developed into an art-based and shopping destination. Bamboo crafts have become distinctive and have been widely traded outside the Pacitan Regency, so this art tourism has more potential to be developed even better with the help of the government and the participation of the surrounding community. In addition, there is Rice Terraces, which is nature tourism that highlights the beauty of the terracing system carried out by the community in Bandar District. Nature tourism that emphasizes rice fields is one step to be able to maintain the sustainability of nature and maintain culture [19]. Based on [20], Sawahan tourism village development is strongly influenced by natural capital and social capital. Natural capital is related to landscapes and ecosystems [21][22]. Social capital is related to the community, which shows that the community must have a way of management that is oriented to the environment and human development, and not only related to profit [23].

\subsection{Amenity}

Amenity is related to the existence of tourism support facilities made by humans, such as lodging, restaurant, toilets, gas station, mosques/churches, and others. The existence of supporting facilities for tourism in rural areas can have a positive impact in the form of increasing the number of tourists and improving the quality of life on the surrounding community [24]. Supporting facilities in the Agropolitan Area include a full range of lodging, eating places, religious facilities, and others. There is only one lodging in this Agropolitan Area, located in the Pakisbaru Village Nawangan District, and other lodging in the same district and in the Bandar District have not been found. However, something that can be done to overcome this is by making lodging at the homes of local resident. Based on [25], lodging in rural areas is usually managed by the community and becomes an option by tourists because it can give an experience of the lifestyle from the rural area community together with its unique culture. So that lodging in the rural area offers not only temporary shelter but also unique experiences that are rarely found in urban or densely populated areas [26]. Based on the results of interviews, it shows that the level of acceptance of the Bandar District community towards tourists and outsiders is relatively high and for the development of tourism there are three main factors which must be considered that are safety, cleanliness, and supporting facilities, in addition to the high participation and desire of the community in managing tourism also has a very important impact on its development [20].

The identification and mapping tourism potential shows that there is not yet the development of tourism support facilities in the surrounding area, so further observation, identification, and mapping are needed to explore the potential of developing supporting facilities in accordance with the type of tourism desired by the community. However, to overcome the problem, each potential tourism destinations can be developed as a camping ground for camping tourism. Camping provides a different experience for tourists because this type of facility provides closeness to nature and the environment, this tour is perfect for local tourists who are bored with the city crowd and foreign tourists who want to enjoy the nature of Indonesia. Camping tourism can provide social and physical benefits such as climbing and many other outdoor activities so that it can affect character building and self-confidence [27]. Camping is also included in one of the steps in achieving sustainable tourism, where there is an environmental education process implicit in it [28]. 


\subsection{Accessibility}

Accessibility is a crucial component of tourism development. Accessibility is supported by infrastructure development. Infrastructure is one of the cornerstones in tourism development, so that the central, provincial, and regional governments must work together to be able to build better infrastructure. The infrastructure consists of the roads leading to tourist sites, the availability of electricity, the availability of cellular networks, the availability of water for tourists, and others. Also, the government must cooperate with the private sector in providing supporting facilities such as accommodation and transportation [15]. Transportation facilities to get to the Agropolitan Area are still limited, most people use private vehicles in the form of motorbikes and cars to travel, but walk is an option too. Public transportation is only available on certain days, and even with a limited distance range at the District government office and the market.

Transportation plays a vital role in tourism development. So, the availability of land and air transportation is needed. Agropolitan Area needs improvements and optimization of land transportation. In line with this, the main infrastructure development of roads is increasingly optimized and accelerated. It is because land transportation is a type of transportation advice that is cheap and easy to obtain, and as much as $70 \%$ of the travel industry in the world is dominated by land transportation such as cars, motorbikes, and bicycles. Also, the advantages of land transportation are demonstrated by its ability to reach tourist sites with difficult terrain or in rural areas [29].

\subsection{A Synergy between 3A (Attractions, Amenity, and Accessibility) for Tourism Development}

The synergy of the tourism component, according to [6] (Attractions, Amenities, and Accessibility), is essential for the development of tourism in potential locations. Research from [30] shows that the factors that can be used to develop waterfall tourism areas are an improvement of suggestions and infrastructure (road widening, road improvement, and guidance), development of supporting facilities, community empowerment, promotion, and must aim to preserve the environment.

The existence of attractions that are supported by the presence of a functional accessibility component will make tourists consider spending their time even if only just come and want to know about the attractions provided. Besides, the presence of amenities such as lodging, hotels, and guest houses become a positive value that will make tourists spend a long time in these tourism destinations. However, if the development of hotels, lodging, and guest houses is still considered not too important, tourists can be directed to sleep in people's homes. It will give tourists a new sensation as well as a means of introducing the culture, traditions, and habits of the local community. By integrating these three components, the opportunity to push the Agropolitan Area into a sustainable tourist destination will be more increasing. However, the role of the government is crucial in providing support in the form of training, promotion, and development of the area by involving the community in the process. So, that tourism destinations can be created that can improve aspects of people's lives, especially economic aspects. 


\section{Conclusion}

Based on the identification and mapping that has been done in the Agropolitan Area with Secondary Data Review and interviews which are then compiled with maps using the participatory asset mapping method. Potentials that have been identified then classify based on component 3A indicate that the attractions component is (Curug/Waterfall, Cave, Plateau (Mountain/Hill), Handicraft Center, Plantation, Culture, and Springs), Amenity component is a Hotel in Pakisbaru Nawangan. But still, the house can also be used as lodging, other supporting facilities that are quite complete, and the Accessibility component shows that the road conditions are good enough, although it must be further developed, especially in giving directions. The synergy between all components can encourage the development of excellent and sustainable tourism so that it can improve the economy of the community around the Agropolitan Area Pacitan Regency.

\section{References}

[1] K. P. Umum, “Agropolitan dan Minapolitan Konsep Kawasan Menuju Keharmonian.” Jakarta, 2012.

[2] B. T. Suroyo and W. Handayani, "Pengembangan Kawasan Agropolitan di Kabupaten Kulonprogo Daerah Istimewa Yogyakarta (Agropolitan Development in Kulonprogro Regency, Yogyakarta)," J. Reg. City Plan., vol. 25, no. 3, pp. 243-261, 2014.

[3] R. C. Arionesei, G; Pavel, S.; Andrei-Alexandru, M.; Maria, "Tourism Today: Why is It a Global Phenomenon," Conf. Pap., 2014.

[4] Badan Pusat Statistik (BPS), Statistik Indonesia 2019. Jakarta: BPS, 2019.

[5] G. C. Pascariu and R. Tiganasu, "Tourism and sustainable regional development in Romania and France: an approach from the perspective of new economic geography," Amfiteatru Econ. $J$, vol. 16, no. Special No. 8, pp. 1089-1109, 2014.

[6] A. Yoeti Oka, "Ekonomi Pariwisata: Introduksi, Informasi, dan Implementasi," Jakarta: Kompas, 2008.

[7] G. Brown, "Mapping landscape values and development preferences: a method for tourism and residential development planning," Int. J. Tour. Res., vol. 8, no. 2, pp. 101-113, 2006.

[8] R. Baggio and C. Cooper, "Knowledge transfer in a tourism destination: the effects of a network structure," Serv. Ind. J., vol. 30, no. 10, pp. 1757-1771, 2010.

[9] J. H. Van der Merwe and A. Van Niekerk, "Application of geospatial technology for gap analysis in tourism planning for the Western Cape," S. Afr. J. Sci., vol. 109, no. 3-4, pp. 1-10, 2013.

[10] A. Alfian, F. W. Sulistyadi, P. D. Samuel, and E. Naitio, "Ecotourism Attractions, Level of Satisfaction and Management of Air Terjun Kembar in Kampung Anyar Village, Banyuwangi," J. Indones. Tour. Dev. Stud., vol. 4, no. 1, pp. 37-42, 2016.

[11] H. M. Ijeomah, "Urashi Waterfall Ecotourism Development and Cultural Challenges in Dikenafai, Ideato South Local Government Area, Nigeria," African Res. Rev., vol. 3, no. 4, 2009.

[12] M. Bemanian, F. Ahmadi, A. Sadeghi, and A. Baharlou, "Improving Environmental Quality of Margoon Waterfall Protected Area through Sustainable Tourism Development in the Region," J. Sustain. Dev., vol. 3, no. 3, p. 243, 2010.

[13] M. Kostić, M. Lakićević, and S. Milićević, "Sustainable tourism development of mountain tourism destinations in Serbia," Econ. Agric., vol. 65, no. 2, pp. 843-857, 2018.

[14] P. Ramet, J.; Tolvanen, A.; Kinnunen, I.; Torn, A.; Orell, M.; Siikamaki, "Sustainable Tourism," 2005. .

[15] E. E. Okonkwo, E. Afoma, and I. Martha, "Cave Tourism and its Implications to Tourism 
Development in Nigeria: A Case Study of Agu-Owuru Cave in Ezeagu,” Int. J. Res. Tour. Hosp, vol. 3, pp. 16-24, 2017.

[16] M. Rindam, "Cave tourism: The potential of asar cave as a natural tourism asset at Lenggong Valley, Perak," in SHS Web of Conferences, 2014, vol. 12, p. 1014.

[17] I. Frochot, "A benefit segmentation of tourists in rural areas: a Scottish perspective," Tour. Manag., vol. 26, no. 3, pp. 335-346, 2005.

[18] E. Kastenholz, D. Davis, and G. Paul, "Segmenting tourism in rural areas: the case of North and Central Portugal," J. Travel Res., vol. 37, no. 4, pp. 353-363, 1999.

[19] I. G. Pitana, "Rice-Based Culture and Tourism Development in Bali," Univ. Udayana., J. Din. Kebud., vol. 3, pp. 115-121, 2003.

[20] S. K. Parmawati, R;, Rif'atul, I.; Lutvita, E.R.; Muhammad, I.R.; Agung, "Ecotourism Development Strategy of Bukit Jaddih Karst, Madura," J. Indones. Tour. Dev. Stud., vol. 6, no. 2, pp. 113-119, 2018.

[21] M. De Wit, H. van Zyl, D. Crookes, J. Blignaut, T. Jayiya, V. Goiset, and B. Mahumani, "Investing in natural assets. A business case for the environment in the City of Cape Town," Rep. Prep. City Cape Town, Cape Town, South Africa, vol. 18, pp. 294-302, 2009.

[22] K. Brandl, "Sustainable Tourism mand Nature Conservation: An Investment in Our Future," 2017.

[23] S. D. Putri, S. Soemarno, and L. Hakim, "Strategic management of nature-based tourism in Ijen crater in the context of sustainable tourism development," J. Indones. Tour. Dev. Stud., vol. 3, no. 3, pp. 123-129, 2015.

[24] D. Vail, "Amenity Investments \& Tourist Destination Development," Augusta Maine Cent. Econ. Policy, 2010.

[25] S. A. Jamal, N. Othman, and N. M. N. Muhammad, "Tourist perceived value in a communitybased homestay visit: An investigation into the functional and experiential aspect of value," $J$. Vacat. Mark., vol. 17, no. 1, pp. 5-15, 2011.

[26] H. Tucker and P. Lynch, "Host-guest dating: The potential of improving the customer experience through host-guest psychographic matching," J. Qual. Assur. Hosp. Tour., vol. 5, no. 2-4, pp. 11-32, 2005.

[27] H. Xiao and S. L. J. Smith, "The making of tourism research: Insights from a social sciences journal," Ann. Tour. Res., vol. 33, no. 2, pp. 490-507, 2006.

[28] A. Marin-Pantelescu, "The perspective of camping tourism in Romania," Acad. J. Econ. Stud., vol. 1, no. 4, pp. 45-53, 2015.

[29] I. J. Musa and B. A. Ndawayo, "The role of transportation in the development of tourism in Nigeria.," Tourismos, vol. 6, no. 1, 2011.

[30] R. P. Putra, A.C.D.; Setiawan, "Faktor Penentu Pengembangan Kawasan Wisata Air Terjun Dlundung Berbasis Partisipasi Masyarakat," J. Tek. Pomits, vol. 2, no. 1, pp. 1-5, 2013. 